\title{
CONCEPTUAL CO-PRESENCE OF MOTION AND EMOTION IN THE ESTONIAN TERMS OF PERSONALITY
}

\author{
Ene Vainik, Toomas Kirt, Heili Orav
}

\begin{abstract}
The purpose of the study was to find out whether the conceptual connection of emotion and motion is holding in the domain of personality traits. In a quantitative study 40 Estonian terms of personality traits were investigated and a conclusion was driven that, indeed, the qualities of emotionality and motion are perceived as co-present characteristics. In further data analysis some visualized measures were applied in order to get further insights into the hidden structure of the data. The self-organizing map (SOM) analysis revealed an additional dimension of axiological evaluations present in the semantics and the SOM meta-analysis technique revealed groups of near synonymous words as well as gave overview of the more general structure common in the two data sets. The latter was tentatively explained by the person's habitual level of activation.*
\end{abstract}

Keywords: motion, emotions, terms of personality traits, semantics, self-organizing map, Estonian

\section{Introduction}

We consider the vocabulary of personality traits as a potential meeting point of emotion and motion in the human conceptual representation of other peoples' behaviour. It has been claimed that conceptual knowledge influences our experience of other people (Feldman Barrett 2006: 28). The general idea is that our knowledge of people and situations automatically and effortlessly shapes what we "see" people doing and gives rise to our explanations for that behaviour. One aspect of such conventional knowledge is the idea that a person's emotion and physical mobility are somehow linked. Several observations back up our assumption that those three phenomenamotion, emotions and personality traits - could be conceptually linked.

* This study was supported by grant no. 7149 of the Estonian Science Foundation and grant no. MJD22 financed with 
First, there is a conceptual connection between emotions and motion. Both psychologists and some cognitive linguists share an agreement that emotions are linked to a tendency of motion either towards or away from something (see Gibbs 2006: 243 and his references). ${ }^{1}$ Motion as a more embodied and experience related cognitive domain serves as a source to conceptualize emotional phenomena metaphorically. There are such conceptual metaphors mentioned in the literature as A CAUSED CHANGE OF STATE (EMOTION) IS MOTION CAUSED BY A FORCE; CONTROL OVER AN EMOTIONAL ACT IS CONTROL OVER MOTION; EMOTIONAL RESPONSES ARE OTHER-PROPELLED MOTIONS (Kövecses 2000: 58-59).

Second, there is a connection between tendencies to move and certain personality traits. Motivational psychology differentiates between two important motivation styles which it formulates directly as motion tendencies - a tendency to approach the goal and a tendency to avoid (withdraw from) the anti-goal (Carver et al. 2000). Both emotional disposition and motivation are identified as significant components of the structure of personality (Nõlvak, Valk 2003).

Third, there is an area of intersection between vocabularies of personality traits and emotions. Studies into psychology and linguistics alike have shown that concerning the content, vocabularies describing personal qualities and emotions are partly overlapping (Plutchik 1980, Szelid, Geeraerts 2008, Vainik, Orav 2005).

Our research question is whether the conceptual interrelatedness of motion and emotion also holds in the domain of personality traits. Our intuition is that it does - i.e. we set a hypothesis that emotions and motion are co-present in the conceptualizations of personality traits. We have already approached this research question in a previous qualitative study that enabled to find out the main ways in which the domain of physical motion is exploited in order to conceptualize emotionrelated aspects of character terms (Vainik, Orav 2009). In that previous study we applied the framework of cognitive metaphor theory (Lakoff, Johnson 1980, 1999) and systematic detection of basic embodied image-schemas (Johnson 1987, Peña Cervel 2003). However, this previous analysis was based mostly on the linguist's insights into the lexicon and its underlying mechanisms and did not say much about the co-presence of emotionality and mobility in the character terms for an ordinary speaker of Estonian.

Our theoretical framework of concepts is based on the Peter Gärdenfors' (2000) theory of conceptual spaces which distinguishes three non-competing levels of representations. In this model the most abstract level is the symbolic level on which an observation is described by means of some symbol system (e.g., language). The second level is the conceptual level on which observations are located as points or an area in the conceptual space. The least abstract level is the sub-conceptual level on which the observations are characterized by inputs from sensory receptors which form the quality dimensions of the conceptual space. The quality dimensions thus form a (perceptual) basis for conceptual representation which in turn can be communicated by means of the respective linguistic units.

When applied to the field of personality traits, this would mean that on the most abstract level we have terms of personality traits, on the conceptual level we have concepts of personality traits and on the sub-conceptual level we have discrete (e.g., perceptual) qualities of personality. While asking people to assess some qualities

This is implied even by the fact that the English terminology - the terms emotion and motion - are derived from the same Latin root movere, 'to move'. The term motivation originates from the same Latin root (The Concise Oxford Dictionary). 
of a person characterized by a specific term we are using an access on the most abstract level (a term of personality trait). At the same time we are addressing the perceptual qualities of the assessed person (the subconceptual level). As a result the intermediate, conceptual level of representation is revealed which would otherwise not be accessible as such. While a personality trait term evokes co-presence of some qualities (e.g., emotionality and mobility) in the inquiry addressed to the subconceptual perception it would most probably also mean the co-presence of those qualities on the conceptual level i.e. their co-conceptualization.

In addition, the theory offers a geometrical model of assessing concept similarity based on spatial relations. As Gärdenfors (2000) has suggested, there is an analogy between the conceptual spaces and the self-organizing map (Kohonen 2000). During the self-organizing process the points in high-dimensional space are mapped onto a two-dimensional output map that can be identified as a conceptual space. The self-organizing map is one way of modeling how the geometric structure of concepts can be created.

In the present study we focus on detection whether the two qualities of personality - emotionality and mobility - are truly perceived and conceptualized as co-present in the case of character traits' terms. In order to do so we used character terms as verbal stimuli and gathered assessments of emotionality and mobility given by laypersons. We subjected the quantitative data to statistical analysis and in the next phase of the study we applied the methods of data reduction, which give the results in the form of visual layouts. Both traditional statistical analysis and visualized measures taken together revealed that, indeed, the qualities of emotionality and motion are perceived as co-present characteristics. The visualized measures gave some further insights into the data, too. The self-organizing map (SOM) analysis revealed an additional dimension of axiological evaluations present in the semantics and the SOM meta-analysis technique revealed groups of nearly synonymous words as well as gave an overview of the more general structure common in the two sets of data. The latter was tentatively explained by the person's habitual level of activation.

\section{Materials and procedures}

\subsection{Selection of the terms}

The initial data pool of linguistic expressions for our analysis was gathered by Orav (2006) using the field method of tasks of free listing (Corbett, Davies 1997). In a multiple-test series, the participants $(\mathrm{N}=100$; age 14-90; the number of men and women was balanced) had to list words in Estonian that describe a person's internal characteristics. ${ }^{2}$ A total number of about 1270 words were elicited (Orav 2006).

The next step was to select the terms which to address to in a quantitative study. The number of the verbal stimuli could not exceed 50 because the purpose was to use ordinary speakers of Estonian on a voluntary basis and they had to fill in two independent questionnaires. Therefore the number of terms under investigation was limited to 40 and in addition 10 controls were selected.

\footnotetext{
2 The test subjects were illustratively explained the difference between words describing external characteristics and internal qualities (i.e. personality). External traits are connected mostly with people's looks (as thin, blonde, big), but internal are those characteristics which we can register only by observing someone's behaviour.
} 
As the next step, two of the authors (Heili Orav and Ene Vainik) assessed the total list of words independently, relying on their intuition and introspection. ${ }^{3}$ Although the evaluation criteria were left open deliberately, the result was a great concurrency in terms of words associated with motion tendencies (87\%). Even though the total number of words making reference to emotions was nearly twice as high, there was less concurrence in the independent assessments (70\%). While selecting the terms both researchers had mutually independently used two criteria as a basis for introspect decisions: a) the meaning of the word as a whole suggested motion or emotion (e.g., kïre 'fast', emotsionaalne 'emotional'), or b) the word or phrase was clearly derived from some certain motion verb (e.g. heitlik 'fickle, lit. throw+ADJ') or emotion term, (e.g. rõõmsameelne 'joyful, lit. joy$\mathrm{SG}+\mathrm{GEN}+$ mind +ADJ').

For further testing we selected those character terms that both authors had independently assessed as motion-related and at least one of the authors had assessed as emotion-related. The controls were selected so that both authors agreed that 5 of them had to do only with motion tendencies (sportlik 'sporty', kiire 'fast', laisk 'lazy', virk 'diligent', edasipüüdlik 'ambitious, lit. forward+pursue+ADJ') and 5 of them only with emotions with no reference to motion whatsoever (kade 'envious', õel 'mean', rõõmsameelne ‘joyous', tundlik 'sensitive', närviline 'nervous').

\subsection{The experiment}

The data was gathered in April 2008 during two weeks via electronic media (by means of e-formular http://www.eformular.com). The experiment consisted of two questionnaires directly addressing the two qualities under investigation (see Appendix 1). The questionnaires had to be completed in serial order-at first the questionnaire about emotionality and next about mobility. There was one question that occurred in both questionnaires: "To what extent is a person characterised as $X$ (a specific character term) also emotional/mobile?"The questions were followed by the 50 words $(40+10)$. At the end of both questinnaires there was a place to fill in the data about the age and gender.

Every word was evaluated twice by every person on a 5 point Likert-scale (very little, somewhat, fairly, above average, very much emotional/mobile). A possibility was also left open to skip a word in the case the person would think that the given quality (emotionality/mobility) had nothing to do with the specific presented character term. This possibility was used very little and unsystematically.

\subsection{Participants}

The inquiry was carried out by electronic media and it was out of our reach to direct the selection of participants in terms of age, gender or educational background. The appeal to fill in those two questionnaires was spread out in the Internet through a network of family members and friends and their contacts. Apparently, it was filled in by persons who were cooperative enough and happened to have time. It took approximately 45 minutes altogether to fill in both questionnaires.

\footnotetext{
3 For information about introspection as a method in linguistics (see e.g. Huumo 2008) and cross-references. Assessment of word lists by two independent experts in order to find words suitable for some semantic category has been widely used in psychology (see e.g. Aavik, Allik 2002).
} 
The eventual number of participants was $\mathrm{N}=161(\mathrm{~F}=142, \mathrm{M}=19)$, age averaged at $32,8(\mathrm{SD}=12,0)$.

\subsection{Handling of the data}

The verbal assessments on Likert-scale were transformed into numerical values ranging down from 5 (very much) to 1 (very little). It was carefully detected whether the rows of the two tables matched the persons (relying on the data about age and gender and computer address given by e-formular).

In the following analysis the data was first analyzed statistically to find out the average levels and standard deviations of emotionality and mobility ratings associated with our stimulus terms. In order to detect systematic intercorrelations between ratings of emotionality and mobility the analysis of bivariate correlations was carried out (two-tailed T-test). As the next step the visual methods of dataanalysis were applied in order to find out some further structure possibly hidden in the distribution of the numeric data.

\subsection{Self-organizing maps}

The self-organizing map (SOM) (Kohonen 2000) is a widely used method to visualize multidimensional data. The SOM can be used to project multidimensional data into in a two-dimensional map while preserving proximity relationships as well as possible. The data items located close to each other in multidimensional space will appear as nearby units in a two-dimensional map.

The learning algorithm of the SOM has a few basic steps which are reiterated a number of times. Prior to learning the output map is initialized randomly. Thereafter one random input unit is chosen and compared with all output nodes on the map to find the closest unit on the output grid. Next, this best match or winning node and its neighborhood are changed to become closer to the input unit, using the following equation:

$$
\begin{aligned}
& \text { Weight }(\mathrm{New})=\text { Weight }(\mathrm{Old})+\text { Learning rate } \times \text { Neighbourhood function } \times \\
& (\text { Input value }- \text { Weight }(\text { Old }))
\end{aligned}
$$

During the learning process the learning rate and the neighbourhood function shrinks. As a result of this process the output becomes ordered and all the output vectors are valued so that the total distance from the input vectors is minimized.

The distance between each pair of map units is represented on a topological map called the Unified Distance Matrix (U-matrix) by their location and also with colour coding. A bright shade corresponds to a small distance between two map units and a dark shade represents a bigger difference between the map units. The points on the output map that lie in the light area belong to the same group or cluster, while the dark area shows the borders between the clusters. 


\subsection{Method of comparing the self-organising maps}

As the SOM represents data on a two-dimensional topological map another question arises: how to measure similarity of two or more maps describing similar data? This study proposes a methodology of SOM meta-analysis (Kirt, Vainik, Võhandu 2007) that uses the local neighbourhood as the basis to measure the similarity between maps. The method expects the neighbourhood relations to remain stable even when the overall orientation of the map changes. The proposed methodology to measure similarity between the self-organizing maps consists of two main stages.

First, to analyze general organization the resulting map is visually examined and clusters and their borders are identified, in addition the general orientation and locations of data items are also identified. Thereafter the matrix of neighbourhood relations is formed. Neighbourhood assessment is based on the location of the best matching units (BMU - a point on the map that is the closest to the input data vector) on the self-organizing map. Two data items are neighbours if they are marked to locate on the same node or in the neighbouring nodes depending on the neighbourhood range. The second part of the similarity measurement consists of establishing how much the two neighbouring matrixes are identical to what is a maximum isomorphic subset. Here we can perform a new meta-level analysis and reorder and visualize the isomorphic sub-graph to see commonly shared information between two maps. For output the Graphviz ${ }^{4}$ software has been used.

The next stage of similarity analysis is the calculation and assessment of similarity coefficients. The similarity measurements coefficients have typically values between 0 and 1 . Value 1 indicates that the two objects are completely similar and value $o$ indicates that the objects are not similar at all. Two similarity coefficients Simple Matching Coefficient (SMC) and Jaccard Coefficient (J) (see Tan, Steinbach, Kumar 2005) - have been used. The SMC rates positive and negative similarity equally and can be used if positive and negative values have equal weight. Jaccard Coefficient $(\mathrm{J})$ is used if the negative and positive matches have different weights (are asymmetric). Jaccard Coefficient ignores negative matches and can be used if the variables have many o values.

\section{Results}

The results in terms of mean values, standard deviations and correlations between evaluations given to the same word in the two tasks are given in Appendix 2. Observations of the mean values of assessed emotionality and mobility showed that there was covariation in the rates: one part of the terms rated high on both emotionality and mobility and the other part rather low on both. There were no terms rating high on one scale and low on the other. The highest ratings of both emotionality and mobility were given to terms hüperaktiüne 'hyperactive', pidurdamatu 'rampant', pöörane 'frenetic' and the lower ratings on both qualities to apaatne 'apathetic', flegmaatiline 'phlegmatic', loid 'listless', passiivne 'passive', tagasihoidlik 'modest', uimane 'sluggish'. There are, of course, variations in the levels of emotionality and mobility co-present in the meanings of the words. For

4 Graph Visualization Software available from http://www.graphviz.org/ (20.02.2010). 
example in the meanings of aktiivne 'active', elav 'lively', energiline 'energetic', püsimatu 'restless', reibas 'cheery', the rate of mobility prevailed while in the case of ründav 'offensive', temperamentne 'spirited', äkiline 'quick-tempered', the aspect of emotionality prevailed.

The two-tailed T-test showed that for $45 \%$ of the words there were significant positive correlations $(0,46>\mathrm{r}>0,3 ; \mathrm{p}<0$,0001) between the given rates of emotionality and mobility, on $32 \%$ of the words there were a little less significant and weaker positive correlations $(0,27>\mathrm{r}>0,18 ; \mathrm{p}<0,001)$ and in $23 \%$ of the cases there was still significant $(\mathrm{p}<0,05)$ positive correlation $0,17>\mathrm{r}>0,09$.

A conclusion can be drawn that in the case of studied 40 Estonian terms both emotionality and mobility were either present or non-present in their meanings in a correlated way. One can say that these two characteristics were co-conceptualized. Thus, the results of the statistic analysis are in accordance with our intuition that mobility and emotionality are perceived and conceptualized as co-present human qualities in the meanings of Estonian character terms.

As an addition to the test-words 10 terms of personality trait were added to the questionnaires as controls that were supposed to have to do only with one of the two characteristics. Surprisingly, the control words shared the similar pattern of significant positive correlations (see Appendix 3). Only in case of two of the controls tundlik 'sensitive' and rõõmsameelne 'joyous' the correlations were too weak $\mathrm{r}<0,06$ and nonsignificant. There are two explanations: a) the selection of control words failed; b) in the case of any term of personality trait it is possible to assess the presence or absence of both emotionality and mobility as compared to some default norm of these qualities. We assume that both characteristics have to do with the person's habitual level of activation. A person with the habitual level of activation lower than the "norm" is characterized by terms implying low emotionality and low mobility, a person with habitual activation level higher than the "norm" is characterized by terms implying both high emotionality and mobility.

The traditional statistical analysis revealed the significant positive correlation between emotionality and mobility on $90 \%$ of the cases. The strength of correlations did not exceed 0,45 , though, remaining just moderate on most of the cases. In connection with those observations some further questions arise. Is the moderate positive correlation all about the measurable interrelations of emotion and motion in the understanding of personality traits? How are the terms of personality traits similar or dissimilar in their ability to reflect both the person's emotionality and mobility? Is there possibly some kind of hidden structure in the data-matrix that does not show up in the traditional statistical analysis? In an attempt to answer those questions we turned to some of the visual measures of data analysis.

\subsection{The SOM-s of emotionality and mobility}

The next step of our study was to subject the data of assessed emotionality and mobility to the process of self-organization. The respective topological layouts are presented on Figure 1 and Figure 2..$^{5}$ We used the SOM Toolbox (Alhoniemi et al. 2005) for projecting the abstract and numeric properties of data items into a visible and comprehensible code of their relative spatial locations and colour. There are two

\footnotetext{
5 Next to the SOM-s we represent the layouts of concepts in form of Table 1 and Table 2 in order to give the English glosses of the Estonian terms.
} 
principles to keep in mind while interpreting the results: closeness of the map units and a brighter shade of colour on the map also means similarity of data items.

The very first glance at the Figures tells that they are similar in respect of their extended layouts in one dimension. This is of no surprise because both questionnaires measured the level of just one quality, emotionality or mobility, respectively. The concepts which rated higher on those qualities tend to "shrink" to the bottom of the graph and concepts where those qualities were low have "risen" to the uppermost parts of the graphs. However, the overall shape of the graphs is not purely scalar, apparently due to the significant variations of the individual assessments. The rationale of the emergent horizontal dimension remains a question of further interpretation, though.

Table 1. BMU-s of the SOM of emotionality

Figure 1. SOM of emotionality

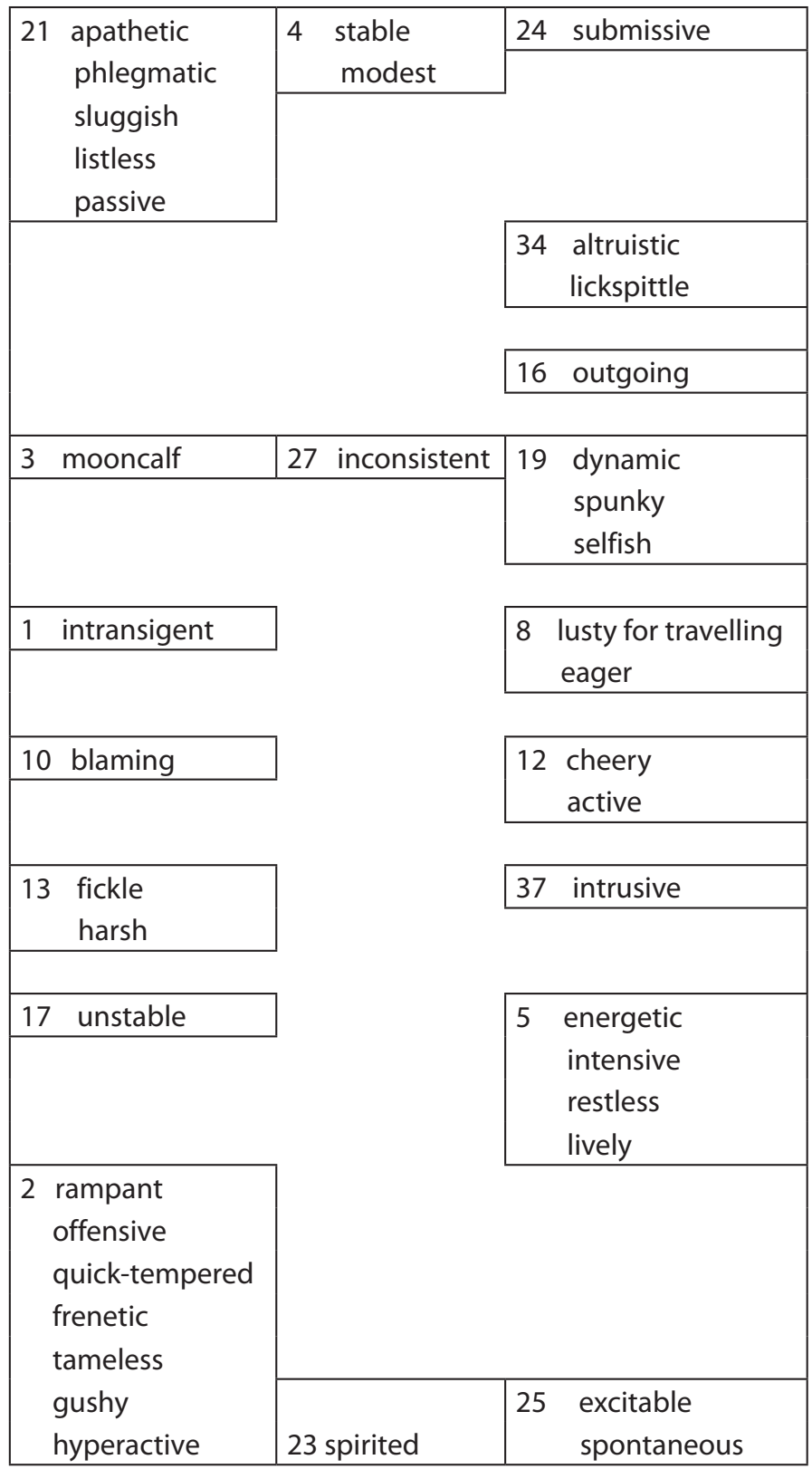

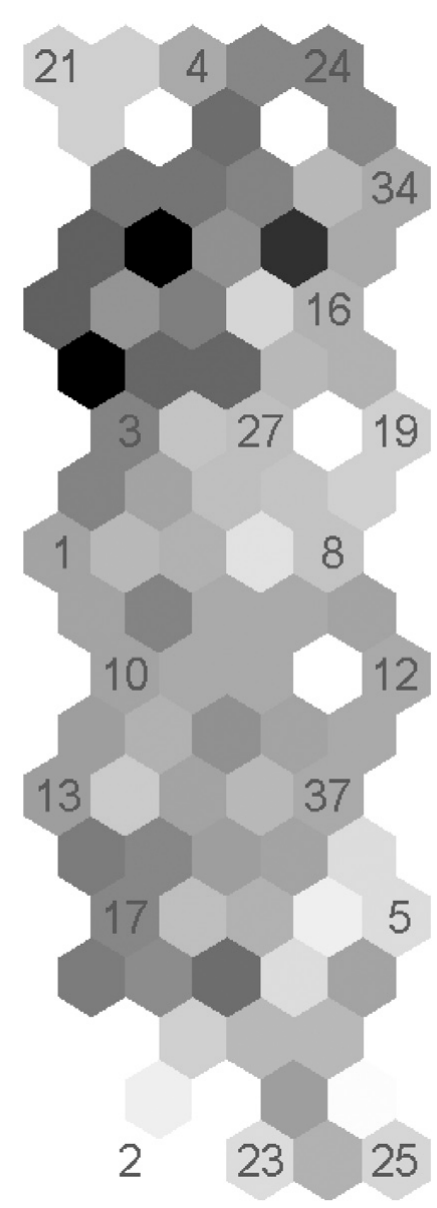


A possibility has been pointed out by Krzeszowski (1997) that the dimension of axiological evaluations is showing up. Interestingly, the location of positive vs. negative concepts is reversed on both graphs and such a distinction is detectable only in the bottom part of the graphs where the emotionality and mobility ratings were the highest. The terms of personality traits referring to very low emotionality and/or mobility are valued negatively, anyway.

Another thing to look at on the maps is the local neighbourhood relations of concepts. Similar data items are located close to each other and different data items are located apart. This principle enables the clusters of concepts to emerge. In both maps there are small clusters in the uppermost left corner that are separated by relatively darker shade of the colour. These are the concepts where the measured qualities occurred at a very low level (apathetic, listless, passive, sluggish, submissive, modest). On Figure 2 there is another darker border of clusters noticeable in the middle section of the graph.

Table 2. BMU-s of the SOM of mobility

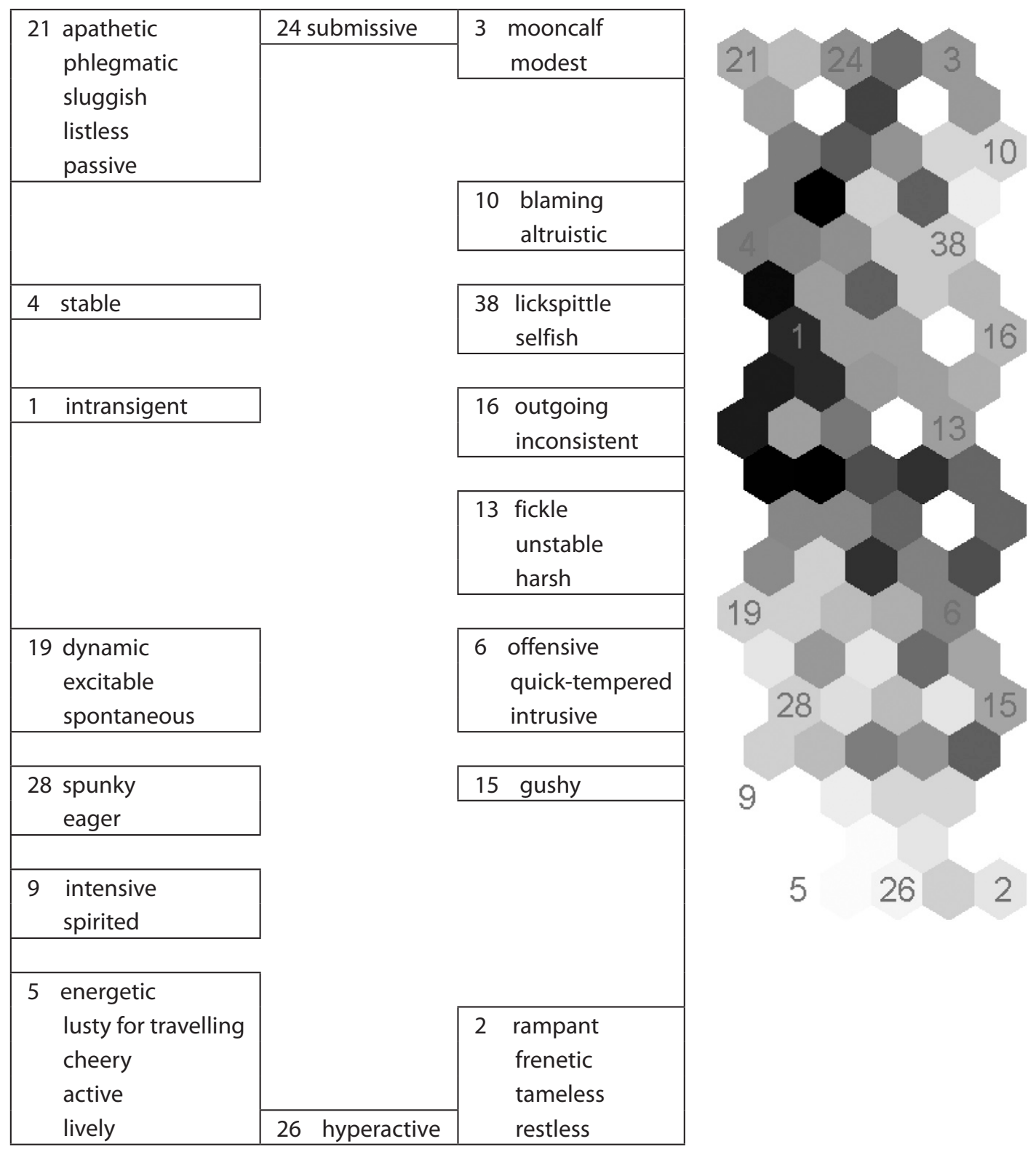

Figure 2. SOM of mobility 
It can be concluded that in the case of the rated mobility the terms of character traits tend to gather into three clusters: very low mobility, intermediate level or normative level of mobility and a cluster of high mobility (in the bottom). In the case of emotionality ratings the concepts are divided into two: a cluster of very low or missing emotionality and a cluster where the level of emotionality gradually decreases from the very high level to intermediate or normative levels.

The third thing to look at on the maps is the local neighbourhood relations of map units. The closer the visual neighbourhood the higher is the rate of similarity of the data. Concepts located in the same cell of the SOM-map are the most similar to each other (in respect of given emotionality and mobility ratings). In Tables 1 and 2 the coincident terms have been separated by cell borders. We can see groups of seemingly near-synonymous concepts on both maps which reveals that as regards to the levels of emotionality and mobility there are no very sharp distinctions made between those concepts. Distinctions are made between those concepts that are not neighbours and do not fall into the same cluster.

In order to answer the question how similar or dissimilar are the local neighbourhood relations on both maps the method of pure visual tackling may not suffice, though. In the next section we use a metaanalytical method of comparing two (or more) SOM maps that share the range of units but may differ in their numerical descriptions and therefore in the topological layouts and local neighbourhood relations describing their similarity.

\subsection{Isomorphic subgraph of the SOM-s of emotionality and mobility}

The aim of the meta-analysis of the SOM was mainly to systematically compare the neighbourhood relations present on both maps and identify similarities between two conceptual spaces. There are 1600 potential neighbourhood relations possible between the pairs of our 40 emotion terms. Only a part of the neighbourhood relations is realized on both maps.

To look for the isomorphic subgraph means to identify those neighbourhood relations that are present on both SOM-s. The neighbourhood matrixes of emotionality and mobility were compared and a matrix of common neighbours was found and visualized. The summary of the neighbourhood relations between the two tasks is given in Table 3. The number of relations was measured with a different range of neighbourhood, starting from 1 to 2 . An increase in the neighbourhood range also causes an increase in the number of relevant neighbourhood relations. The SMC coefficient is decreasing if the neighbourhood is increasing because the growing range increases the possibility of relations between the words that actually do not belong to the same neighbourhood. The SMC can be used as an indicator of stability. The SMC coefficient can also be used if the samples are exclusive like in the case of the lexical study. Jaccard Coefficient is increasing if the neighbourhood range is widening because it characterizes the positive matches and there is a tendency to have more positive matches if the number of neighbourhood relations increases. In both cases the number of positive matches remains rather low and therefore the value of coefficients is also low. 
Table 3. Neighbourhood similarity of the SOM of terms of personality

\begin{tabular}{|c|c|c|c|c|c|c|}
\hline Neig. Range & Emotionality & Mobility & Similar neig. & Total neig. & SMC & Jaccard coef. \\
\hline 1 & 206 & 198 & 76 & 328 & 0,8425 & 0,23171 \\
\hline 2 & 406 & 426 & 216 & 616 & 0,75 & 0,35065 \\
\hline
\end{tabular}

In case the neighbourhood range is provisionally set on 1 , several separate fragments of conceptual networks are formed (Figure 3). The general structure of the data does not appear as a connected system. There are groups of near synonyms that share the estimated level of correlated emotionality and mobility. For example the group of low emotionality/mobility: loid 'listless', apaatne 'apathetic', passiuvne 'passive', uimane 'sluggish', flegmaatiline 'phlegmatic', or the group with high level of correlated emotionality and mobility: pöörane 'frenetic', hüperaktiivne 'hyperactive', taltsutamatu 'tameless', pidurdamatu 'rampant'. There are also groups that share the intermediate level of correlated emotionality and mobility ratings. In addition, there are some concepts visible that are not connected to other concepts like püsimatu 'restless', stabiilne 'stable', temperamentne 'spirited', hõljuja 'mooncalf' etc. These polymorphic units show up in different neighbourhood surroundings on our two maps.

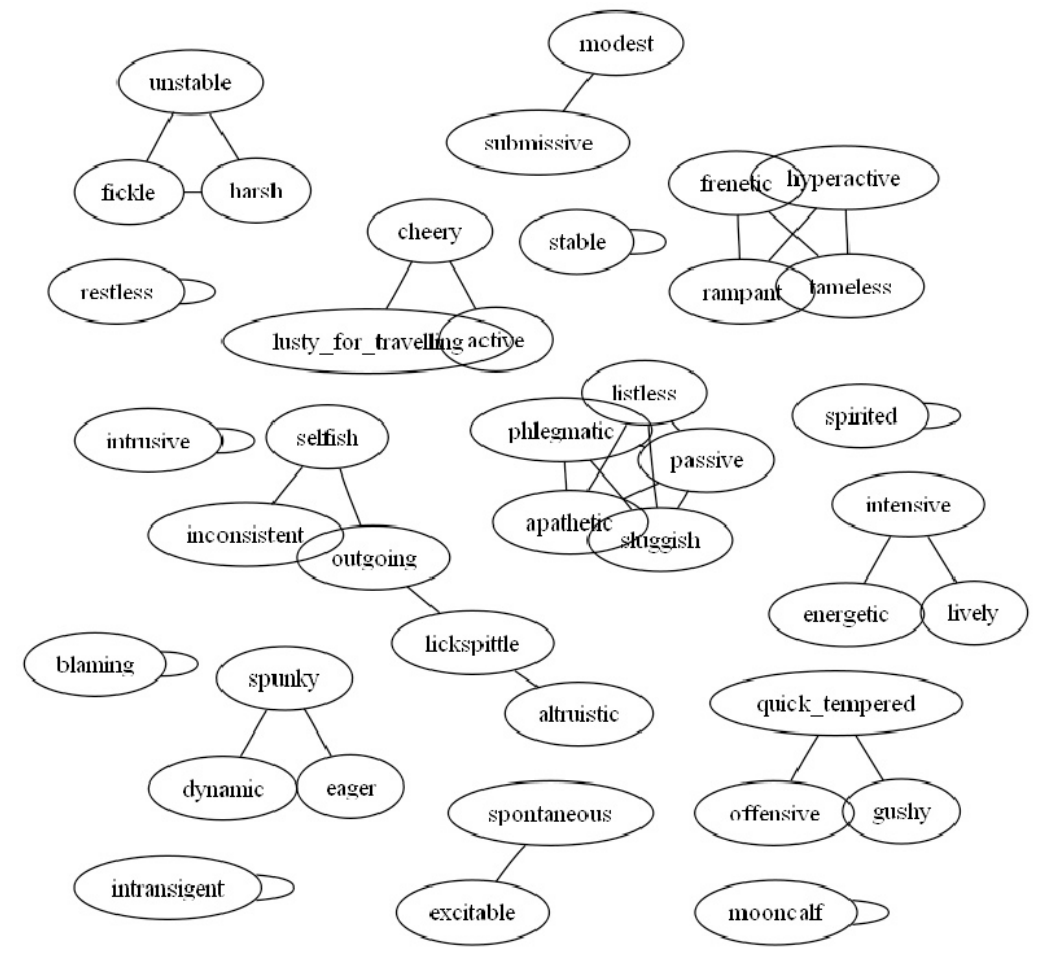

Figure 3. Visualized isomorphic subgraph of terms of personality (emotionality vs. mobility). Neighbourhood range 1

When the measured neighbourhood range is set on 2, the graph becomes connected (Figure 4). An increase in the neighbourhood range also causes an increase in the number of relevant neighbourhood relations. Therefore the graph is not the best means for studying the particular range of neighbours for any single concept. What it is good for is the general overview of the common structure hidden in the two sets of data. It can be speculated that it represents the common structure or a backbone of the data which in our case looks kind of symmetrical. There are at least two almost 
exclusive groups of data visible on the left side and the right side that had the weakest neighbourhood relations. These are the subgroups of low and high emotionality/ mobility accordingly and only the concept järeleandmatu 'intransigent' is situated in the middle having the least to do with both of the groups.

In the section of the results of the traditional statistical analysis we hypothesised about the person's habitual level of activation as a more general property that can cause the levels of emotionality and mobility to covariate. The diagonal dimension of the graph on Figure 4 represents such a more general dimension. Interestingly enough, the term järeleandmatu 'intransingent' represents the intermediate or normative level of activation. It is also visible on the graph that the subgroup of high activation is more differentiated than the group of low activation. The terms in the upper part of the high activation subgroup highlight the person's physical behaviour (mobility) which is evaluated positively while the lower part the of the high activation subgroup highlights lack of emotional regulation skills which is mostly evaluated negatively.

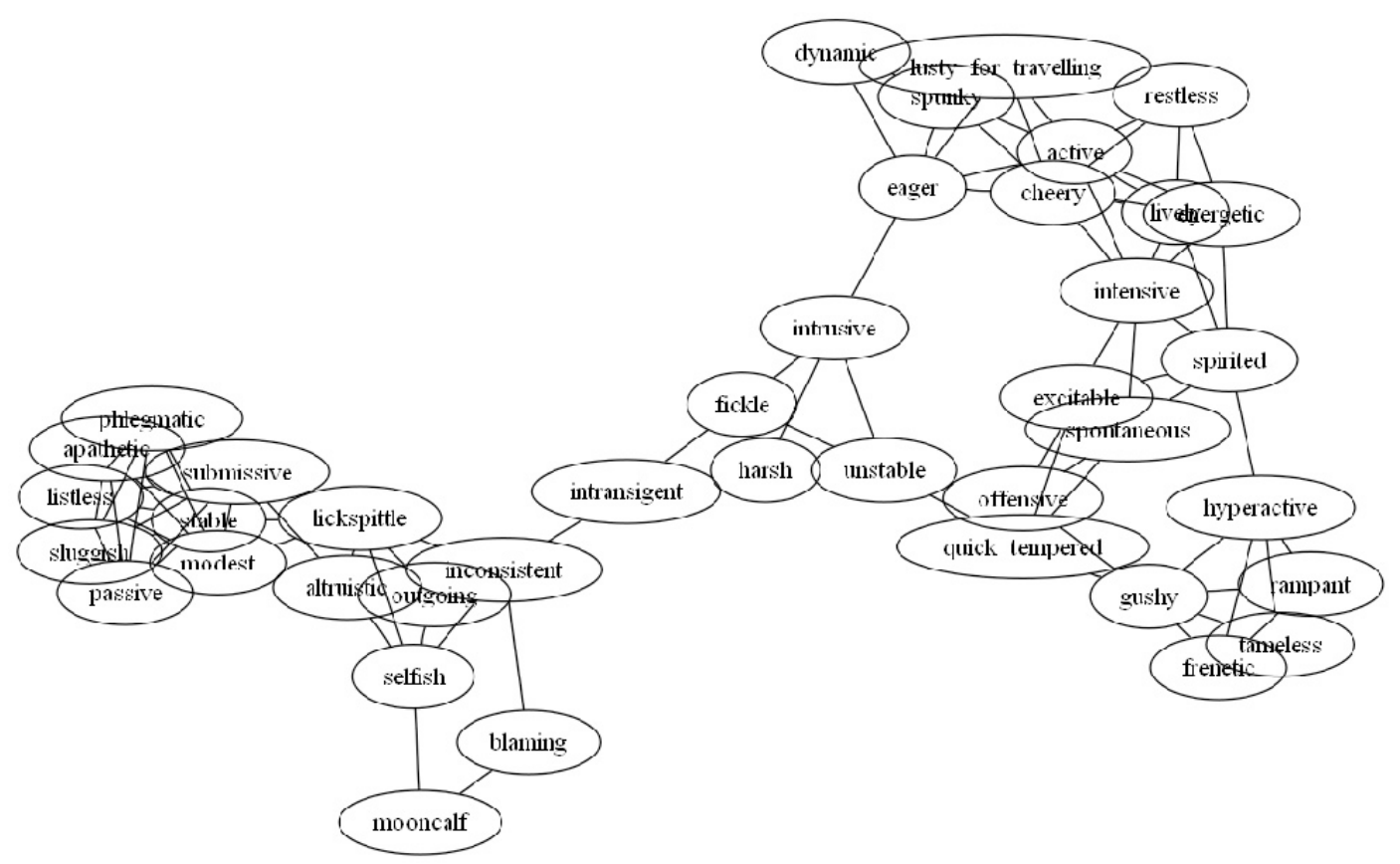

Figure 4. Visualized isomorphic subgraph of terms of personality (emotionality vs. mobility). Neighbourhood range 2

\section{Summary and discussion}

On the basis of the observations of other authors (Carver et al. 2000, Gibbs 2006, Kövecses 2000, Plutchik 1980) as well as our own previous semantic study (Vainik, Orav 2009) we hypothesized that the categories of emotions and physical motion could be conceptually linked and that this connection could be detected in the semantics of the terms of personality. In order to find out whether this conceptual link means co-presence of emotionality and mobility for Estonian laypersons 40 stimulus terms were selected and two inquiries measuring these qualities were carried out. 
As a result we had two sets of data measuring the conceptual co-presence of motion and emotion in the Estonian terms of personality. The traditional statistical analysis gave us the mean values and standard deviations of the given mobility and emotionality ratings; it allowed establishing the intercorrelations and their significance. It occurred that both emotionality and mobility were either present or non-present in the meanings of 40 words in a correlated way. The two-tailed T-test showed significant but rather weak positive correlations between ratings of emotionality and mobility. Our main hypothesis was thus proven - emotionality and mobility occurred as positively correlated throughout almost the whole range of stimulus terms according to the opinions of the Estonian laypersons. None of the correlations was strong, though.

As the traditional statistical analysis was unable to reveal any hidden patterns possibly inherent in the data, the two data sets were further visualized by the method of the Self-Organizing Maps. The SOM-s show kind of extended layouts with the clusters of words of high/low emotionality and mobility respectively. In addition, a dimension of axiological evaluation is recognizable as the horizontal dimension of the layouts. Presence of those dimensions reminds two of the Osgood's three universal factors of activity, potency and evaluation that are claimed to measure the semantic space universally (Osgood, Suci, Tannenbaum 1975). Some other researchers of personality traits (in English) have also ended up in a two-dimensional solution of activation-evaluation circumplex (Plutchik 1980). As regards to the emerging dimension of evaluation it is interesting to pay attention to Orav's (2006) indication that the Estonian personality vocabulary always includes either positive or negative evaluation. The same tendency has been pointed out by Vainik (2004) in the case of emotion vocabulary. Thus, understanding and conceptualising other people's traits and emotions always brings along their approval or disapproval. The importance of implicit evaluation in concept formation has been stressed also by other authors (e.g., Zlatev 2001).

The visualizing techniques enabled to "translate" the abstract and numeric properties of data items into a visible and comprehensible code of their relative spatial locations and colour (SOM) or graphic connection (the meta-analytic tool). Visualization allows getting the first glimpse on the data quickly due to the pictorial superiority effect (Medina $2008^{6}: 233$ ). The limitations of visualization techniques are that sometimes some a priori knowledge is needed to understand what the visualized structure means and how to interpret the results. The most appropriate visualization technique that reveals the peculiarities of the data in the best possible way is not always predictable beforehand and some experimentation might be needed. It is interesting to note that other researchers of emotion and personality terms have used a method called correspondence analysis to get some visual clusters of the data units under investigation (Szelid, Geeraerts 2008).

In order to compare the two topological layouts systematically we used a similarity measurement technique that enabled us to analyze the two sets simultaneously. The meta-analysis of two SOM-maps showed 1) the clusters of nearlysynonymous words with the most correlated emotionality and mobility ratings, 2) the hidden common structure of the two sets of data. The latter supports our intuition about the person's habitual level of activation as the general property explaining the co-variation of mobility and emotionality. We assume that the structural

6 This is a popular book based on peer-reviewed scientific studies. The references for what the author calls a brain rule of visual superiority are retrievable from the site http://www.brainrules.net/pdf/references_vision.pdf (2.03.2010). 
elements which were found to be shared between our two SOM-s (Figure 3 and 4) have the greatest chance of belonging to the conceptual level of representation that is assumed to be on the intermediate position in the hierarchy of abstractness (Gärdenfors 2000).

The three levels of symbolic, conceptual and sub-conceptual representation of personality traits are compatible also with the levels proposed by some students of emotion knowledge (Niedentahl, Setterlund, Jones 1994). The theorists of symbol grounding also claim that the particular symbol system is used to carry our conceptual knowledge and that it is grounded into the surrounding world through the sensory-motor interaction (Harnad 1990). Other authors, however, say that such grounding has some difficulties in representing abstract concepts (Barsalou 2008) and that sensory-motor and conceptual processing are based on same system (Barsalou 2003). Therefore the conceptual knowledge is claimed to be embodied and mapped within a sensory-motor system (Gallese, Lakoff 2005).

In the present experimental study into the Estonian layperson's intuitions we were able to detect to what extent the categories of emotionality and mobility are conceptually co-present in the meanings of a set of Estonian terms of personality traits. The finding of their positive correlation is fully in accordance with the insights of the cognitive psychologists (see Gibbs 2006: 243) as well as cognitive semanticsists (see Kövecses 2000: 58-59). Understanding the conceptual components of character trait terms is important for the general theory of person perception. In a sense, person perception is the study of the theory of mind - how the categorization process allows people to attribute mental states to identify, explain, and predict behaviour (Feldman Barrett 2006: 28).

$\begin{array}{ll}\text { Abbreviations } \\ \text { A.SBST } & \text { agentive substantive } \\ \text { ADJ } & \text { adjective } \\ \text { CAR.ADJ } & \text { caritive adjective } \\ \text { GEN } & \text { genitive } \\ \text { INF } & \text { infinitive } \\ \text { PRS.PTCP } & \text { present participle } \\ \text { SG } & \text { singular }\end{array}$

\section{References}

Aavik, Toivo; Allik, Jüri 2002. The structure of Estonian personal values: A lexical approach.European Journal of Personality, 16, 221-235. doi:10.1002/per.439

Alhoniemi, Esa; Himberg, Johan; Parhankangas, Juha; Vesanto, Juha 2005. SOM Toolbox (Version 2.0). [Computer software and manual.] http://www.cis.hut.fi/projects/ somtoolbox/ (11.11.2005).

Barsalou, Lawrence W. 2003. Situated simulation in the human conceptual system. - Language and Cognitive Process, 18 (5-6), 513-562. doi:10.1080/01690960344000026

Barsalou, Lawrence W. 2008. Grounded cognition. - Annual Review of Psychology, 59, 617-645. doi:10.1146/annurev.psych.59.103006.093639

Carver, Charles S.; Sutton, Steven K.; Scheier, Michael F. 2000. Action, emotion, and personality: Emerging conceptual integration. - Personality and Social Psychology Bulletin, 26 (6), 741-751. doi:10.1177/0146167200268008 
Corbett, Greville G.; Davies, Ian R. L. 1997. Establishing basic color terms: Measures and techniques. - C. L. Hardin, L. Maffi (Eds.). Color Categories in Thought and Language. Cambridge: Cambridge University Press, 197-223.

Feldman Barrett, Lisa 2006. Solving the emotikon paradoks: Categorization and the experience of emotion. - Personality and Social Psychology Review, 10 (1), 20-46.

Gallese, Vittorio; Lakoff, George 2005. The brain's concepts: The role of the sensorymotor system in conceptual knowledge. - Cognitive Neuropsyhology, 22, 455-479. doi:10.1080/02643290442000310

Gibbs, Raymond W. Jr. 2006. Embodiment and Cognitive Science. Cambridge: Cambridge University Press.

Gärdenfors, Peter 2000. Conceptual Spaces. The Geometry of Thought. London: The MIT Press.

Harnad, Stevan 1990. The symbol grounding problem. - Physica D, 42, 335-346. doi:10.1016/0167-2789(90)90087-6

Huumo, Tuomas 2008. Joko lingvistin nojatuoli joutaisi kaatopaikalle? Introspektiolingvistiikan asemasta kognitiivisessa kielitieedessä. - Emakeele Seltsi aastaraamat, 53 (2007), 163-180.

Johnson, Mark 1987. The Body in the Mind: The Bodily Basis of Meaning, Imagination, and Reason. Chicago, IL: University of Chicago Press.

Kirt, Toomas; Vainik, Ene; Võhandu, Leo 2007. A method for comparing self-organizing maps: Case studies of banking and linguistic data. - Y. Ioannidis, B. Novikov, B. Rachev (Eds.). Proceedings of Eleventh East-European Conference on Advances in Databases and Information Systems. Varna, Bulgaria: Technical University of Varna, 107-115.

Krzeszowski, Tomasz P. 1997. Angels and Devils in Hell. Elements of Axiology in semantics. Warszawa: Wydaictwo Energeia.

Kohonen, Teuvo 200o. Self-organizing Maps. 3rd ed. Springer Series in Information Sciences Series, 30. Berlin: Springer.

Kövecses, Zoltan 2000. Metaphor and Emotion. Language, Culture and Body in Human Feeling. Studies in Emotion and Social Interaction. Cambridge: Cambridge University Press.

Lakoff, George; Johnson, Mark 1980. Metaphors We Live By. Chicago, London: The University of Chicago Press.

Lakoff, George; Johnson, Mark 1999. Philosophy in the Flesh: The Embodied Mind and its Challenge to Western Thought. New York: Basic Books.

Medina, John 2008. Brain Rules. Seattle: Pear Press.

Niedenthal, Paula M.; Setterlund, Marc B.; Jones, Douglas E. 1994. Emotional organization of perceptual memory. - P. M. Niedenthal, S. Kitayama (Eds.). The Hearts Eye. Emotional Influences in Perception and Attention. New York: Academic Press, 87-113.

Nõlvak, Aire; Valk, Raivo 2003. Isiksus ja emotsioonid. - J. Allik, A. Realo, K. Konstabel (toim.). Isiksusepsühholoogia. Tartu: Tartu Ülikooli Kirjastus, 171-191.

Orav, Heili 2006. Isiksuseomaduste sõnavara semantika eesti keeles. Dissertationes linguisticae Universitatis Tartuensis, 6. Tartu: Tartu Ülikooli Kirjastus.

Osgood, Charles E.; Suci, George J.; Tannenbaum, Percy H. 1975 [1957]. The Measurement of Meaning. Urbana-Chicago: University of Illinois Press.

Peña Cervel, Sandra M. 2003. Topology and Cognition: What Image-Schemas Reveal about the Metaphorical Language of Emotions. LINCOM Studies in Cognitive Linguistics. Munich: Lincom Europa.

Plutchik, Robert 1980. Emotion: A Psychoevolutionary Synthesis. New York: Harper \& Row Publishers.

Szelid, Veronika; Geeraerts, Dirk 2008. Usage-based dialectology. Emotion concepts in the Southern Csango dialect. - Annual Review of Cognitive Linguistics, 6, 23-49.

The Concise Oxford Dictionary 1999. The tenth edition. Oxford: Oxford University Press. 
Tan, Pang-Ning; Steinbach, Michael; Kumar, Vipin 2005. Introduction to Data Mining. Boston: Addison Wesley.

Vainik, Ene 2004. Lexical Knowledge of Emotions: The Structure, Variability and Semantics of the Estonian Emotion Vocabulary. Dissertationes linguisticae Universitatis Tartuensis, 5. Tartu: Tartu Ülikooli kirjastus.

Vainik, Ene; Orav, Heili 2005. Tee tööd ja näe vaeva, ... aga ikka oled vihane. - Keel ja Kirjandus, 4, 257-277.

Vainik, Ene; Orav, Heili 2009. Edasipüüdlik, aga tagasihoidlik. Eesti keele kehapõhised kujutelmad isikuomadustest. - Keel ja Kirjandus, 11, 830-840.

Zlatev, Jordan 2001. A hierarchy of meaning systems based on value. - C. Balkenius, J. Zlatev, H. Kozima, K. Dautenhahn, C. Breazeal (Eds.). Proceedings of the First International Workshop on Epigenetic Robotics: Modeling Cognitive Development in Robotic Systems. Lund University Cognitive Studies, 85. Lund: LUCS, 153-162.

Ene Vainiku (Eesti Keele Instituut) uurimisobjektiks on eesti keele emotsioonisõnavara, selle struktuur, semantika ja varieerumine. Huvipakkuvateks teemadeks on ka psühholingvistika, kognitiivne semantika ja keele ning emotsioonide interaktsioon laiemalt.

Ene.Vainik@eki.ee

Toomas Kirti (Tartu Ülikooli kognitiivse psühholoogia labor) peamised uurimisvaldkonnad on andmeanalüüs, neurovõrgud, iseorganiseerumine, (tehis)intellekt.

Toomas.Kirt@mail.ee

Heili Orava (Tartu Ülikooli eesti ja soome-ugri keeleteaduse instituut) peamised uurimisvaldkonnad on (leksikaalne, kognitiivne, arvuti-) semantika.

Heili.Orav@ut.ee 
Appendix 1. Copies of the headers of the 2 e-formulars

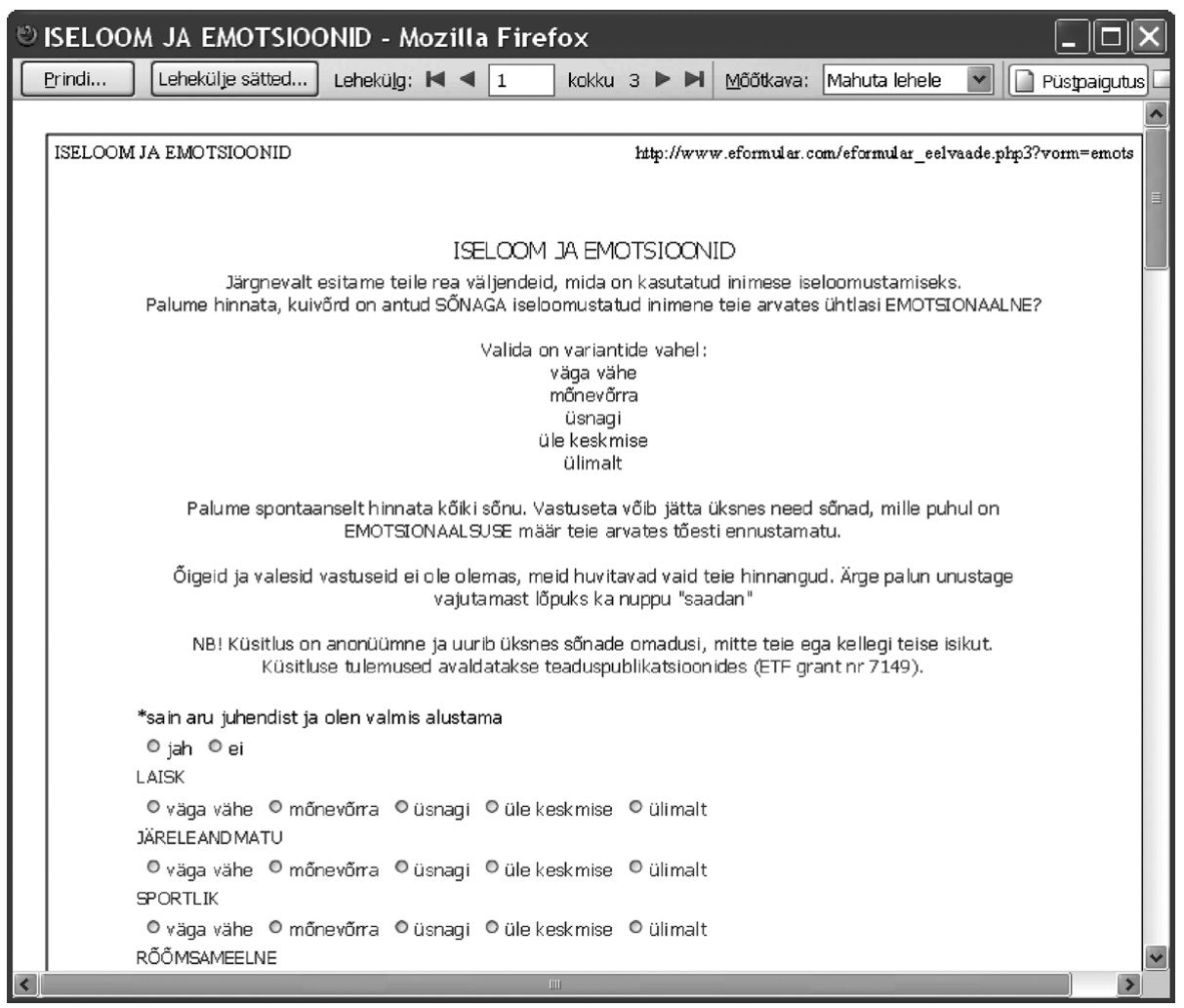

ISELOOM JA LIIKUVUS - Mozilla Firefox

Prindi... Lehekülje sätted... Lehekülg: $\mathbf{M} 41$ kokku $3 \rightarrow \mathbf{M}$ Mõõtkava: Mahuta lehele $\vee$

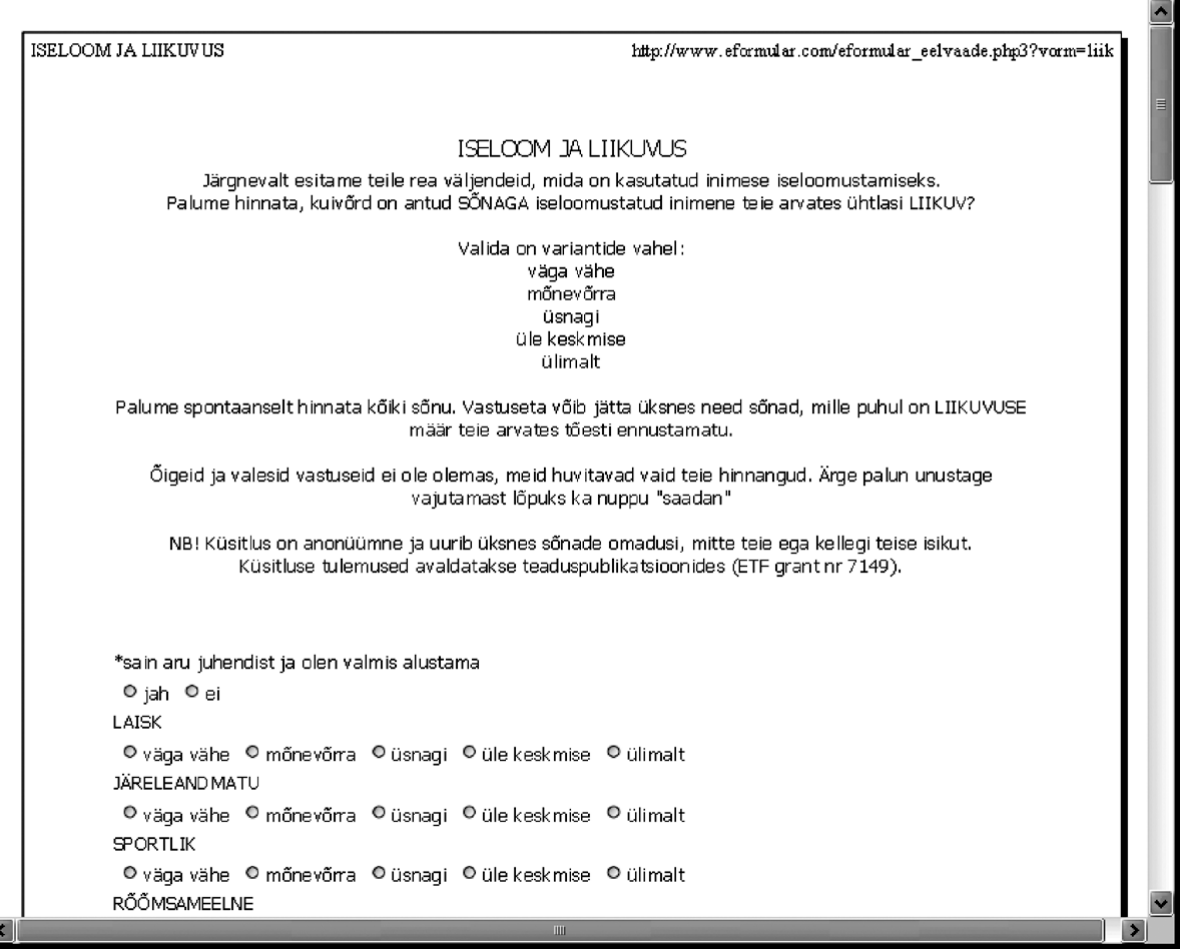

Both formulars conatained $50(40+10)$ character terms presented in a serial order and followed directly by the 5 -point Likert-scale. Choosing the rate of emotionality/mobility was optional. At the end of both questionnaires there was a place to fill in the data about the age and gender. 
Appendix 2. Data gathered about the 40 Estonian terms

\begin{tabular}{|c|c|c|c|c|c|c|c|}
\hline $\begin{array}{l}\text { Estonian term } \\
\text { of character } \\
\text { trait }\end{array}$ & $\begin{array}{l}\text { English } \\
\text { translations }\end{array}$ & $\begin{array}{l}\text { Glosses of } \\
\text { the figurative } \\
\text { expressions } \\
\end{array}$ & $\begin{array}{c}\mathrm{E}_{-} \\
\text {mean }\end{array}$ & $\begin{array}{c}E_{-} \\
\text {StDev }\end{array}$ & $\begin{array}{c}\mathbf{L}_{-} \\
\text {mean }\end{array}$ & $\begin{array}{c}L_{-} \\
\text {StDev }\end{array}$ & $\begin{array}{c}\text { Correlation } \\
\text { E\&L }\end{array}$ \\
\hline flegmaatiline & phlegmatic & & 1,715 & 0,982 & 1,428 & 0,723 & $0,464^{* * *}$ \\
\hline pugeja & lickspittle & hole up+A.SBST & 2,4 & 0,972 & 2,322 & 0,93 & $0,425^{* * *}$ \\
\hline $\begin{array}{l}\text { omakasu- } \\
\text { püüdmatu }\end{array}$ & altruistic & $\begin{array}{l}\text { self+interest- } \\
\text { sG+GEN+pursue+ } \\
\text { CAR.ADJ }\end{array}$ & 2,128 & 0,892 & 2,216 & 0,895 & $0,417^{* * *}$ \\
\hline hasartne & excitable & & 3,869 & 0,975 & 3,629 & 0,841 & $0,409 * * *$ \\
\hline spontaanne & spontaneous & & 3,827 & 0,989 & 3,541 & 0,939 & $0,407^{* * *}$ \\
\hline loid & listless & & 1,478 & 0,805 & 1,258 & 0,673 & $0,384^{* * *}$ \\
\hline temperamentne & spirited & & 4,201 & 0,842 & 3,937 & 0,871 & $0,357^{* * * *}$ \\
\hline vastutulelik & outgoing & against+come+ADJ & 2,586 & 0,962 & 2,617 & 0,858 & $0,353^{* * * *}$ \\
\hline $\begin{array}{l}\text { omakasu- } \\
\text { püüdlik }\end{array}$ & selfish & $\begin{array}{l}\text { self+interest- } \\
\text { SG+GEN+pursue+ADJ }\end{array}$ & 2,629 & 1,064 & 2,404 & 1,04 & $0,347^{* * *}$ \\
\hline ebajärjekindel & inconsistent & $\begin{array}{l}\text { non+track-sG+ } \\
\text { GEN+firm }\end{array}$ & 2,74 & 1,068 & 2,352 & 0,978 & $0,338^{* * *}$ \\
\hline ründav & offensive & attack+PRS.PTCP & 4,182 & 0,937 & 3,44 & 1,05 & $0,336^{* * *}$ \\
\hline passiivne & passive & & 1,548 & 0,737 & 1,39 & 0,67 & $0,326^{* * *}$ \\
\hline apaatne & apathetic & & 1,75 & 1,178 & 1,216 & 0,491 & $0,324^{* * * *}$ \\
\hline taltsutamatu & tameless & tame-INF+CAR.ADJ & 4,219 & 0,966 & 4,043 & 0,951 & $0,324^{* * * *}$ \\
\hline pöörane & frenetic & turn+ADJ & 4,437 & 0,81 & 4,143 & 0,893 & $0,324^{* * * *}$ \\
\hline uimane & sluggish & & 1,422 & 0,73 & 1,264 & 0,623 & $0,317^{* * * *}$ \\
\hline dünaamiline & dynamic & & 2,817 & 1,04 & 3,652 & 0,998 & $0,307^{* * * *}$ \\
\hline hüperaktiivne & hyperactive & & 4,164 & 0,999 & 4,708 & 0,648 & $0,306^{* * *}$ \\
\hline pidurdamatu & rampant & restrain-INF+CAR.ADJ & 4,248 & 0,975 & 4,081 & 0,942 & $0,271^{* *}$ \\
\hline pealetükkiv & intrusive & onto+strive+PRS.PTCP & 3,462 & 1,066 & 4,248 & 0,975 & $0,27^{* *}$ \\
\hline püsimatu & restless & stay+INF+CAR.ADJ & 3,522 & 1,018 & 4,275 & 0,894 & $0,267^{* *}$ \\
\hline järsk & harsh & steep & 3,335 & 1,172 & 2,686 & 0,941 & $0,259^{* *}$ \\
\hline heitlik & fickle & throw+ADJ & 3,563 & 1,039 & 2,704 & 0,991 & $0,25^{* *}$ \\
\hline järeleandmatu & intransigent & after + give+CAR.ADJ & 3,075 & 1,154 & 2,383 & 0,976 & $0,235^{* *}$ \\
\hline hõljuja & mooncalf & hover+A.SBST & 2,76 & 1,191 & 2,081 & 0,798 & $0,233^{* *}$ \\
\hline stabiilne & stable & & 2,013 & 0,901 & 2,21 & 0,822 & $0,231^{* *}$ \\
\hline pealehakkaja & eager & upon+start+A.SBST & 3,006 & 0,884 & 3,785 & 0,744 & $0,23 * *$ \\
\hline äkiline & quick-tempered & sudden+ADJ & 4,255 & 0,91 & 3,503 & 1,004 & $0,222^{* *}$ \\
\hline tagasihoidlik & modest & backwards+hold+ADJ & 1,942 & 0,868 & 1,782 & 0,622 & $0,218^{* *}$ \\
\hline ebastabiilne & unstable & & 3,8 & 1,017 & 2,73 & 1,039 & $0,203^{* *}$ \\
\hline elav & lively & & 3,671 & 0,842 & 4,107 & 0,628 & $0,185^{* *}$ \\
\hline etteheitev & blaming & ahead+throw-PTCP & 3,161 & 1,089 & 2,125 & 0,924 & $0,168^{*}$ \\
\hline $\begin{array}{l}\text { reisimishimu- } \\
\text { line }\end{array}$ & $\begin{array}{l}\text { lusty for travel- } \\
\text { ling }\end{array}$ & & 2,987 & 1,072 & 4,219 & 0,722 & $0,167^{*}$ \\
\hline intensiivne & intenseive & & 3,648 & 1,044 & 3,931 & 0,776 & $0,163^{*}$ \\
\hline tragi & spunky & & 2,679 & 0,883 & 3,762 & 0,72 & $0,153^{*}$ \\
\hline aktiivne & active & & 3,182 & 0,961 & 4,422 & 0,598 & $0,117^{*}$ \\
\hline energiline & energetic & & 3,562 & 0,998 & 4,344 & 0,643 & $0,108^{*}$ \\
\hline ülevoolav & gushy & over+flow+PRS.PTCP & 4,352 & 0,93 & 3,717 & 0,995 & $0,106^{*}$ \\
\hline allaheitlik & submissive & down+throw+ADJ & 2,155 & 1,058 & 1,551 & 0,592 & $0,103^{*}$ \\
\hline reibas & cheery & & 3,258 & 0,917 & 4,163 & 0,611 & $0,092^{*}$ \\
\hline
\end{tabular}

Note: Boldfaced are the mean values that are equal or greater than 4 , highlighted by italics are the mean values less than or equal to 2 . The significance of correlations: ${ }^{* *} p<0,0001 ;{ }^{* *} p<0,001 ;{ }^{*} p<0,05$. 
Appendix 3. Data gathered about the 10 control terms

\begin{tabular}{|l|l|l|c|c|c|c|c|}
\hline $\begin{array}{l}\text { Estonian term of } \\
\text { character trait }\end{array}$ & English & Gloss & $\begin{array}{c}\mathbf{E}_{-} \\
\text {mean }\end{array}$ & $\begin{array}{c}\mathbf{E}_{-} \\
\text {StDev }\end{array}$ & $\begin{array}{c}\mathbf{L}_{-} \\
\text {mean }\end{array}$ & $\begin{array}{c}\mathbf{L}_{-} \\
\text {StDev }\end{array}$ & $\begin{array}{c}\text { Correlation } \\
\text { E\&L }\end{array}$ \\
\hline närviline & nervous & & $\mathbf{4 , 0 8 2}$ & 0,962 & 3,481 & 0,974 & $0,335^{* * *}$ \\
\hline edasipüüdlik & ambitious & $\begin{array}{l}\text { forward+ } \\
\text { pursue+ADJ }\end{array}$ & 2,576 & 0,878 & 3,497 & 0,900 & $0,328^{* * *}$ \\
\hline õel & mean & & 2,875 & 1,083 & 2,062 & 0,878 & $0,283^{* * *}$ \\
\hline laisk & lazy & & 1,650 & 0,790 & 1,294 & 0,658 & $0,210^{* *}$ \\
\hline virk & diligent & & 2,500 & 0,939 & 3,857 & 0,805 & $0,190^{* *}$ \\
\hline kade & envious & & 2,801 & 1,153 & 1,822 & 0,748 & $0,142^{*}$ \\
\hline sportlik & sporty & & 2,550 & 1,094 & $\mathbf{4 , 6 0 9}$ & 0,634 & $0,109^{*}$ \\
\hline kiire & fast & & 2,866 & 1,055 & $\mathbf{4 , 3 3 1}$ & 0,687 & $0,101^{*}$ \\
\hline tundlik & sensitive & & $\mathbf{4 , 1 8 2}$ & 0,928 & 2,422 & 0,907 & 0,051 \\
\hline rõõmsameelne & joyous & & 3,975 & 0,908 & 3,875 & 0,687 & 0,045 \\
\hline
\end{tabular}

Note: Boldfaced are the mean values that are equal or greater than 4 , highlighted by italics are the mean values less than or equal to 2 . The significance of correlations: ${ }^{* * *} p<0,0001 ;{ }^{* *} p<0,001 ;{ }^{*} p<0,05$. 


\title{
LIKUMISE JA EMOTSIOONIDE \\ KAAS-KONTSEPTUALISEERIMINE \\ ISIKUOMADUSTE SÖNAVARAS
}

\author{
Ene Vainik, Toomas Kirt, Heili Orav
}

Eesti Keele Instituut, Tartu Ülikool, Tartu Ülikool

Käesoleva artikli eesmärgiks oli kontrollida, kas hüpotees liikumise ja emotsioonide kaas-kontseptualiseerimisest isikuomaduste sõnavaras vastab tõele. Uuringu keelematerjalina kasutasime Orava poolt 2003. aastal läbi viidud isikuomaduste loetelukatsete tulemusi (1272 keelendit), millest sõltumatute eksperthinnangute baasil eraldati potentsiaalselt nii liikumisega kui emotsioonidega seotud väljendid (106). Uurijate intuitsioone emotsioonide ja liikumise ko-kontseptualiseerimise esinemise ja määra kohta kontrolliti küsitluste abil, milles osales 162 inimest (e-formular). Uurimise all oli 40 testsõna (nt apaatne, pealetükkiv, temperamentne, hüperaktiiune), mille kõigi puhul tuli esile positiivne korrelatsioon emotsionaalsus- ning liikuvushinnangute vahel. Selline empiiriline tulemus näitab, et keelekõnelejad tajuvad neid kahte karakteristikut inimese iseloomus koosesinevatena.

Lisaks traditsioonilisele analüüsile kasutasime oma uuringus ka iseorganiseeruvate kaartide (ingl self-organizing map, SOM) meetodit, et tuua välja andmete varjatud struktuur ning muuta tulemused visualiseerimise läbi kergesti haaratavaks.

Iseorganiseeruvate kaartide meetod kujutab endast edasisidega neurovõrku, mis läbi iseorganiseerumise protsessi projitseerib paljumõõtmelise sisendandmestiku kahemõõtmelisele väljundkaardile, paigutades sarnased sisendid lähestikku. Kasutades kaartide lokaalse naabruse sarnasuse eeldust saime hinnata erinevate kaartide sarnasust, mõõtes nende lokaalsete naabrussuhete vastavust. Artiklis esitatud kahe SOM-kaardi meta-analüüs näitab 1) lähisünonüümsete sõnade "kobaraid" koos kõige rohkem korreleerunud emotsioonide ning liikumise näitajatega 2) kahe andmehulga varjatud üldist struktuuri. Tulemustest nähtuvad kõrge/madala emotsionaalsuse ja mobiilsusega iseloomusõnade hulgad ning ka sõnade semantikasse peidetud aksioloogilised hinnangud - nii positiivsed kui ka negatiivsed. See tõestab veelkord, et iseloomusõnu ja emotsioone tajutakse alati kas meeldivate või ebameeldivatena.

Võtmesõnad: liikumine, emotsioonid, isikuomadused, semantika, iseorganiseeruvad kaardid, eesti keel 